\title{
12
}

\section{Invisible women at war in the West: An archaeology of the Australian Women's Army Service camp, Walliabup (Bibra Lake), Western Australia, c. 1943-1945}

\author{
Sven Ouzman, Jillian Barteaux, Christine Cooper and the \\ UWA Archaeology Fieldschool Class of 2017
}

\section{Introduction}

Imagine travelling from Tasmania and eastern Australia across the Nullarbor Plain, crammed into the back of an open army truck, during the height of summer, to a World War II bush camp where you perform a plethora of essential duties, only for history then to do its best to forget you.

This daunting scenario captures something of the lived experience of the women of the Australian Women's Army Service (AWAS), an under-researched component of Australia's World War II efforts (but see Beveridge 1988; Tucker 1991). Half-forgotten examples like the AWAS are nonetheless instructive in pointing the way to identifying and making known the specific and partial ways in which we remember large, global events like wars (cf. Symonds 2019). For example, wars often deploy tactics like deliberate concealment for operational or political reasons (cf. Burke et al. 2020). The benefit of archaeology is that it is often capable of 'ground-truthing' events known or hinted at through historical and oral sources, by finding the everyday 'small things forgotten' (cf. Deetz 1977) that are essential to a more comprehensive and democratic retelling of the past. Until as recently as a few decades ago, events like world wars, dating to within the last 100 years or so, were not considered suitable for archaeological study because archaeology had not then fully understood its own development and ambit-and because these events were seen as too recent and painful to permit objective study (cf. Baker 1988; Pollard and Banks 2005)—although John Carman says such studies are 'combined ideally with the testimony of those involved-[to give] archaeologists the opportunity to "turn the dead silence into an eloquent statement of experience"'(Carman 1997:2; see Carman 2013 on the value of studying conflict). We now have a well-developed subdiscipline of contemporary archaeology (GravesBrown et al. 2013), yet there are still under-studied areas. World War II is one such area, typically much less of a focus than the archaeology of World War I-especially in Australia, with relatively few sites on Australian soil either studied or accorded heritage site status. This imbalance is largely 
because 'battlefield archaeology' remains the most prominent field of study in conflict archaeology (e.g. Beck et al. 2002) and most Australian world war sites never saw actual conflict; these sites are predominantly abroad (e.g. Gallipoli and Kokoda).

This chapter contributes to the under-reported archaeology of recent conflict on at least three fronts. First, it is about World War II (but see Clark 2018 for a growing archaeological scholarship). Second, it is not a 'battlefield archaeology' (cf. Sutherland 2017) but about a site far behind the frontlines that never saw any 'action'. Finally, it is about women.

Even so, our report details the results of an eight-day University of Western Australia fieldschool in 2017, showing we had great difficulty in 'finding' clear evidence that a site at Bibra Lake, approximately $20 \mathrm{~km}$ south-south-west of Perth, was an army camp, never mind gendering any of its places or artefacts. We explore the utility of archaeology, combined with archival sources and oral histories, in identifying sites of war such as camps, as well as the lived experiences of army personnel, especially women and other subaltern groups. We begin by supplying the background, context and 'facts' of our work, before moving to a more conceptual treatment of the archaeologies of war and women, concluding with thoughts on war and its memorialisation and role in present-day Australia.

\section{Background: A campground then and now}

\section{An Aboriginal home and hearth}

The place Noongar/Nyungar people call 'Walliabup', which may mean 'place of tears' on account of funerary rites held there (Lyon 1833:64-65), is also known as 'Bibra Lake', located approximately $20 \mathrm{~km}$ south-south-west of Perth in Western Australia (Figure 12.1). This area is characterised by 19 lakes and wetlands and has been a landscape of Aboriginal occupation and endeavour for thousands of years, with multiple camping, food-gathering, trade and ceremonial sites listed on the Western Australian Department of Planning, Lands and Heritage's Aboriginal Heritage Inquiry System (Department of Planning, Lands and Heritage 2020-2021). In 1973 Sylvia Hallam (1987) documented over 2000 quartz and other stone tools and stone tool fragments going back at least c. 5000 years, as well as historic artefacts such as reworked glass and clay pipes, which show a continuing occupation and attachment. This work was followed up and extended by Hook and Dortch (2017), who found more non-local quartz, chert and granite artefacts, and also charcoal. Their work was collaborative and Traditional Owners suggested these finds - usually located on higher-lying areas — matched their received knowledge of people camping on higher ground.

The reworked glass shows that this area was a 'contact zone' between Aboriginal people and non-Aboriginal invaders/settlers after the 1829 CE establishment of the Swan River Colony (Bracknell and Collard 2012:85-87). Aboriginal people continued to camp and live in this area until at least the 1980s (Bracknell and Collard 2012:88; testimony of Henry Ford) when the construction of the 'Adventure World' water park in 1982 served to force most remaining people out. This did not extinguish the recent, contested nature of this landscape, with the most recent iteration being the 2016-2017 Liberal State Government's unsuccessful plans to extend the Roe 8 Highway through this site (Chambers and Jennings 2017). Indeed, the fieldschool that produced the data for this article was to help provide empirical details of the area's heritage footprint, used to best manage and ameliorate development. The Roe 8 extension was stopped with the change in state government in 2017 but was reactivated in the 2021 state elections. Walliabup continues to remain important to Nyungar-Whadjuk people's maintenance of identity, being and health (Polglaze 1986). 


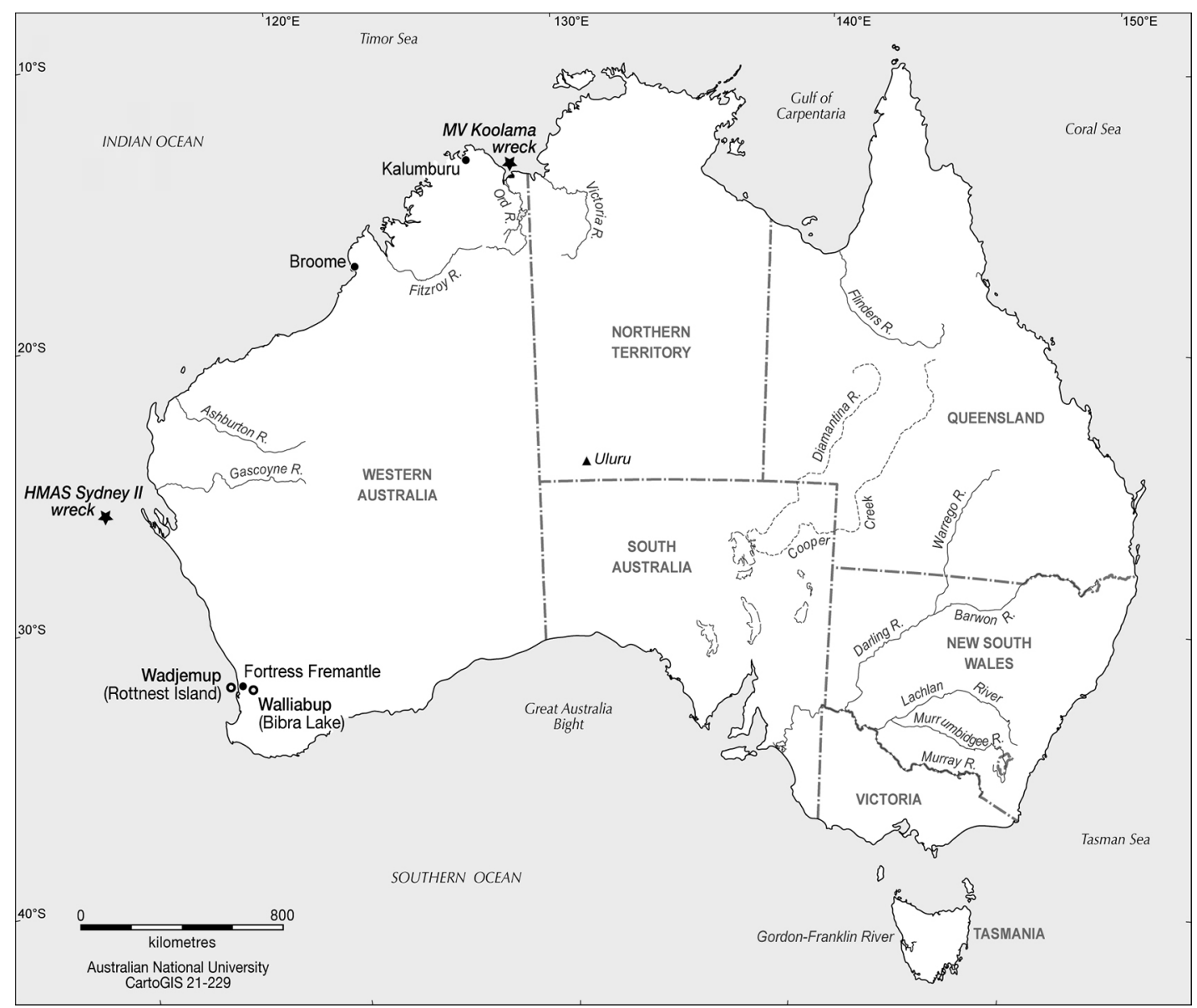

Figure 12.1. Location of World War II sites mentioned in text including Walliabup (Bibra Lake). Source: Rentia Ouzman and ANU CartoGIS.

The character of the landscape has thus both remained the same-a campground for Aboriginal and army personnel-but also changed, from a place of meeting to a landscape of colonial occupation, war and neoliberal exclusion. It is on this more recent history that we focus, reporting on the often ambiguous and ephemeral archaeological evidence, in tandem with similarly ambiguous archival and oral evidence, in order to better understand the nature of World War II and women's participation in it. We now turn to the militarised history of Walliabup.

\section{An army camp: But which one?}

For over 70 years Walliabup's World War II history was almost forgotten, barely surviving in local memory. For example, one of us (Christine Cooper) heard the testimony of a friend from nearby Coolbelup who mentioned seeing searchlights in the sky as small child during World War II. The Bibra Lakes Residents Association, led by Christine Cooper, felt this almost-forgotten military history of Walliabup needed to be told. A major question to resolve was whether there was ever an AWAS camp at Bibra Lake, or if it was being confused with the 116th Light Anti-Aircraft Regiment's camp and headquarters, the 66th Searchlight Battery-or some combination of these (see also Tucker 1991). Indeed, we also had to consider whether there was ever an army camp at this location. Local memories and histories were incomplete and often contradictory, as is often the case decades after an event, especially something as momentous as a world war (Moshenka 2006), where subsequent memorialisations often skew our understanding of events. Indeed, much of 
the Walliabup war information 'out there' is contained on websites and in non-traditional—and non-refereed-electronic formats. But there was general agreement that whatever heritage was present at the site needed to be investigated so that the City of Cockburn-who in 2015 added the site to the Local Government Inventory as a heritage site (City of Cockburn 2017)—could better manage its heritage inventory. Initially they engaged the University of Western Australia's Society of Exploration Geophysicists Student Chapter in 2015 to conduct a geomagnetic survey that produced some promising but inconclusive results of sub-surface anomalies. A citizen science metal detector survey was also commissioned, which showed several areas of interest across a c. $50000 \mathrm{~m}^{2}$ area, with each sub-surface 'target' flagged. In 2016 the Residents Association engaged Terra Rosa Consulting for a one-day survey that noted in situ concrete features and associated construction material such as bricks and asbestos sheets, with occasional finds of glassware, ceramics and metal artefacts in the surrounding bushland (Terra Rosa Consulting 2016). The Residents Association then approached University of Western Australia (UWA) Archaeology in 2016 for more substantive work and in 2017 an eight-day fieldschool was held on site, combining survey, mapping and excavation, with a watching brief for any Aboriginal artefacts, and which produced a student-authored final report (ARCY3002 2017).

After the bushland to the east of Bibra Lake and North Lake was reconnoitred twice, we felt that Lot 65, Hope Road, Bibra Lake (Figure 12.1) was the most likely location for an army camp based on previous survey results and above-surface features and artefacts. The land is owned by the City of Cockburn, who were very accommodating of the fieldschool and provided all required permits. The South West Aboriginal Land and Sea Council was consulted, and cultural as well as occupational health and safety regulations were put in place. As a component of normal archaeological practice, the ARCY3002 Fieldschool students conducted a literature survey of the area, focusing on any AWAS mentions, so that areas of potential interest could be identifiedespecially given there are at least three candidates for an army camp in this area.

\section{The Australian Women's Army Service (AWAS)}

The AWAS was created on 13 August 1941 with the brief:

to release men from certain military duties for service with fighting units. The service recruited women between the ages of 18 and 45 and they served in a variety of roles including clerks, typists, cooks and drivers. (Heywood 2009; see also Beveridge 1988; Desmond 1988; Oliff 1981; Tucker 1991)

Initially, approximately 1600 women joined the service, and their number peaked at 24206 in 1945 (with 679 receiving rank-mostly lieutenant, with a single, remarkable colonel), before demobilisation in June 1947, with all camps closed. It is unlikely that an AWAS camp would be situated isolated far from any other camps, as theirs was a service brief, so it is probable that they would have been twinned or subsumed into one or both of the following camps.

\section{The 116th Light Anti-Aircraft Regiment (116th LAA)}

Records indicate Lot 65 was also the probable home to the 116th LAA, which was formed in 1942 from the remnants of the disbanded 2nd, 3rd and 116th LAA batteries (Sharp 2002). Our evidence for this derives from the regiment's Intelligence Summary documents (or 'War Diary', which was kept by all camps and is today lodged at the Australian War Memorial in Canberra). For the period 1 January - 31 October 1943, the first clear mention of the 116th LAA at 'Bibra Lake' dates to 9 January 1943 (Australian War Memorial 1943a). Prior to this, the 116th LAA was based at a naval base nearer Fremantle, which was about $11 \mathrm{~km}$ to the north-west. The full entry reads: 
RHQ 116 Aust L A A Regt moved from NAVAL BASE (Map ref; 758258) no established at BIBRA LAKE (map ref; 811315). Move completed by 09:00 hours.

Helpfully, a phone number is listed as 'BIBRA LAKE 1'. Camouflage is said to be 'good' and tellingly 'material borrowed from local inhabitants has provided many comforts and conveniences for the men'. This move was likely prompted by fears Fremantle was a known military nexus vulnerable to attack, and distributing key material and personnel to new, unknown locations was a strategic decision to reduce risk and improve defences for what was then a very fearful and nervous populace. We have not found any mention of an 'AWAS' camp in these Intelligence Summaries, although these are voluminous and somewhat costly to obtain. Most likely, there was technically never an 'AWAS camp', as the AWAS personnel were absorbed into camps like the 116th LAA and/or 66th Searchlight Battery to perform service roles.

\section{The 66th Searchlight Battery (66th SL Bty)}

The other possible entity encamped at or near Lot 65 was the 66th Searchlight Battery. Originally the 66th Anti-Aircraft Company, the 66th SL Bty was another amalgam, this time formed in 1941 out of the 55th Anti-Aircraft Company (Australian War Memorial 1943b). We know the 55th was located on 'North Lake Road' (Bibra Lake) by 1942 (Tucker 1991:64). They were likely twinned with the 116th LAA camp-the idea being that the battery's searchlights would illuminate airborne targets that the 116th LAA would then shoot down, although no such action was ever seen at this site or, indeed, Perth during World War II (though there are reports of Japanese reconnaissance planes from time to time). We know the 66th SL Bty requested AWAS personnel in September 1942 and a year later, AWAS personnel comprised half their non-commissioned personnel (see also Athena 1943 for a contemporary news article on women 'manning' the searchlights). Eileen Tucker, then Eileen Reilly, who was part of the AWAS from 8 April 1942 until 9 May 1946, provides a firsthand account in her book We answered the call (1991). Written almost 50 years after the war, Tucker devotes several pages to the AWAS who were 'attached to the 66 S/L battery and camped at Bibra Lake south of Perth' (1991:78; see also subsequent pages for an engaging series of descriptions of life in the bush including snakes, bushfires and never actually seeing the nearby Bibra Lake). The 66th SL Bty's Intelligence Summaries suggest they were operational by April 1943 at several locations around Perth (Como, Kings Park, Mosman Park and Swanbourne), but no Location Statements mention 'Bibra Lake' specifically. Eileen Tucker mentions a Bibra Lake camp of between 100 and 200 people and provides a large group photograph captioned '66 AA Battery, Bibra Lake' (Tucker 1991:99). This attribution is, however, contested by military historian Graham McKenzie-Smith, who holds that Bibra Lake was too small and limited in infrastructure to be either a searchlight battery or AWAS camp and was more likely home to around 50 personnel from the 116th LAA with five or six AWAS support staff (see Higgins 2015). The 116th LAA is known to have been at this site, but only for less than six months in the first half of 1943, representing a possible overlapping occupation with the 66th SL Bty.

No maps are known to exist of the site/camp from this time, although one of the Intelligence Summaries, written by the 116th LAA's commanding officer Lieutenant-Colonel Henley ?Burton (his surname is only partially legible in the Intelligence Summaries), makes mention of an attached rough sketch of an 'administration block and general layout' (Australian War Memorial 1943a: letter dated 9 January, sketch not found). Oral histories, one or two generations removed, from City of Cockburn residents do suggest an AWAS presence. For example, Ruby (nee Tranter) Hone is reported as being an AWAS member at the Bibra Lake Barracks, where she transported linemen in trucks to Jandakot, Bibra Lakes and Cable Beach near Leighton (Dunn 2015). During fieldwork we also received several anecdotal accounts of a camp in the area. Our post-fieldwork 
research did, however, locate a Sunday Times auction notice from 16 September 1945 (Figure 12.2) and another such notice in The Daily News from October 1945. The Sunday Times notice describes auction Lot 7 as: 'Searchlight Station 10. BIBRA LAKE, COR. OF WARWICK [Warwick road was later renamed Hope Road] AND DIXON ROADS', listing several buildings (kitchen, mess and recreation room $[\mathfrak{E} 75]$, latrines, ablutions and engine shed [£12] 'built over [the] bore' with two 2000-gallon water tanks). Materials listed for sale include asbestos, barbed wire fencing, concrete slabs, cisterns, galvanised iron 'skillion' roofing, piping and timber framing. This auction, authorised by the Commonwealth Disposal Commission, concludes 'this is an exceptional opportunity to secure building material now in short supplyFOR REMOVAL' (italics added). There was thus substantial infrastructure on what is today Lot 65 . The auction notice is clear this is a searchlight station, which would imply a nearby anti-aircraft presence-and service personnel like the AWAS. We now turn to the archaeology of the site to see if we can better identify the use to which Lot 65's structures and artefacts were put to.

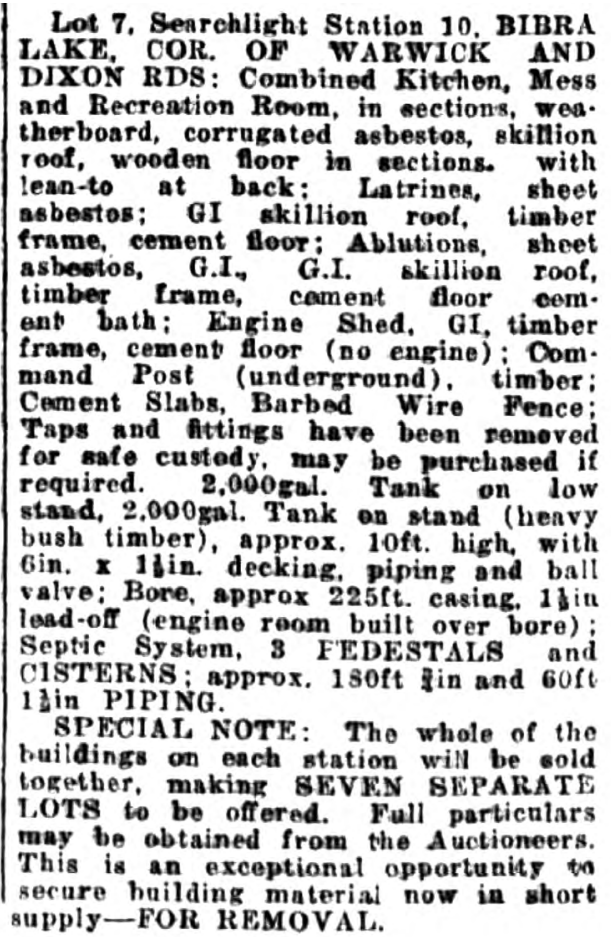

Figure 12.2. Sunday Times auction notice 'Lot 7, Searchlight Station 10', 16 September 1945.

Source: Sunday Times (1945). trove.nla.gov.au/ newspaper/article/59338865.

\section{An AWAS archaeology?}

Primed by these various, sometimes conflicting and partial, sources of information, we set out to see what Lot 65's archaeology could offer-if anything. Between 18 and 24 April 2017, 16 third-year students and two UWA Archaeology staff (SO and JB), assisted by Christine Cooper and local residents, conducted transect survey of a c. $72800 \mathrm{~m}^{2}$ area of Lot 65, Hope Road (Figure 12.3). The terrain is a coastal upland swamp, with banksia and eucalypt woodland, and wetland Melaleuca trees and associated flora, parts of which were converted to extensive market gardens from c. 1890-World War II (Drake and Kenneally 1998). We came across regular scatters of everyday artefacts, such as twentieth- and twenty-first-century bottles, ceramic and metal plates, other metal objects and building rubble. This area only received municipal rubbish removal in the 1970s and is used for illegal dumping so it was very hard to associate any of this material unequivocally with an army camp, which would have used many material culture items indistinguishable from those used by the general population. We could, however, predict a material culture signature in terms of these artefacts' quantity, frequency and context. In the south of our survey area, closer to Hope Road, we noticed extensive compacted limestone paths and larger compacted hardstands, three partial toilets in a concreted row, a septic tank and a concrete pad with metal-piped hole. Immediately north-east of these finds is a large, disturbed 
c. $3.5 \times 4.0 \mathrm{~m}$ square of earth surrounding a depressed interior space that local residents call the 'bunker' and may be what the auction notice refers to as 'command post (underground)' (see Figure 12.3).

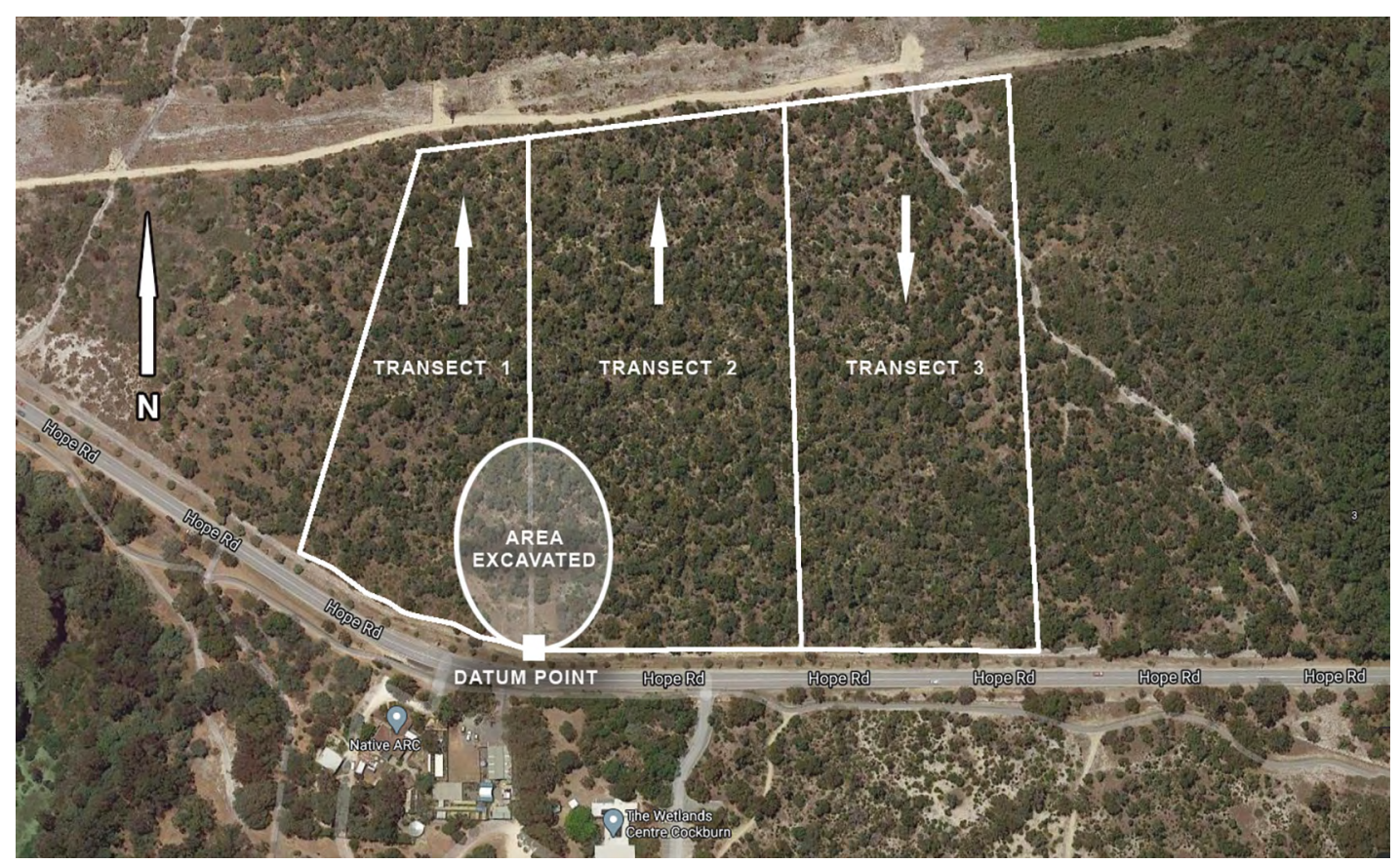

Figure 12.3. Area surveyed and excavated by 2017 UWA Archaeology Fieldschool.

Source: Rentia Ouzman.

\section{Methods}

Our site map (Figure 12.4), derived from 84 total station points, shows substantial limestone paths and hardstanding, with nearby concrete and brick ablution structures, consistent with a medium-term housing of people such as an army camp. The evidence of three toilets, which would not be adequate for a large quantity of people, might support McKenzie-Smith's argument for a smaller, 116th LAA site. However, 'latrines' are mentioned in the auction notice and it may be that the porcelain toilets were for commissioned officers only and the ranks used the usual 'long drops', which would have been accommodated in tents and prefabricated asbestos buildings; but we did not notice any changes in vegetation that might support this theory. We decided to excavate an area of pathway that had what was either collapsed brick walling or bricks used as paving stones, in a $4 \times 1 \mathrm{~m}$ trench (Figure 12.6) and then also the toilet block in a $2 \times 2 \mathrm{~m}$ trench, with a later $2 \times 1 \mathrm{~m}$ trench added to the west (Figure 12.7). Excavation was undertaken in $5 \mathrm{~cm}$ spits owing to a lack of discernible stratigraphy (which would be unexpected at any short-duration site). Measurements of $\mathrm{pH}$ and soil colour were taken, along with bulk soil samples. Nested sieves $(5 \mathrm{~mm}$ and $3 \mathrm{~mm}$ ) were used and at the end of the excavation, sondages were sunk into each trench to a depth of approximately $1 \mathrm{~m}$ through largely undifferentiated sand to test for any Aboriginal artefacts, but with no success. In the final two days of the fieldschool, the concrete pad south-east of the toilet excavation was excavated. This concrete pad may have been an ablution block or washhouse. Test pitting was also undertaken towards the end of the fieldschool in c. 24 of the locations where previous metal detector survey had suggested sub-surface anomalies. These test pits were excavated in $25 \times 25 \mathrm{~cm}$ squares. For division of labour, students were assigned to a trench and rotated duties such as path mapping and public 
engagement, as the excavation was advertised and visits by the public encouraged. Indeed, over 60 members of the public visited us - Aboriginal and non-Aboriginal—in addition to protesters from the nearby Roe 8 campaign. In some cases, people shared tantalising memories of war and other times of Walliabup/Bibra Lake.

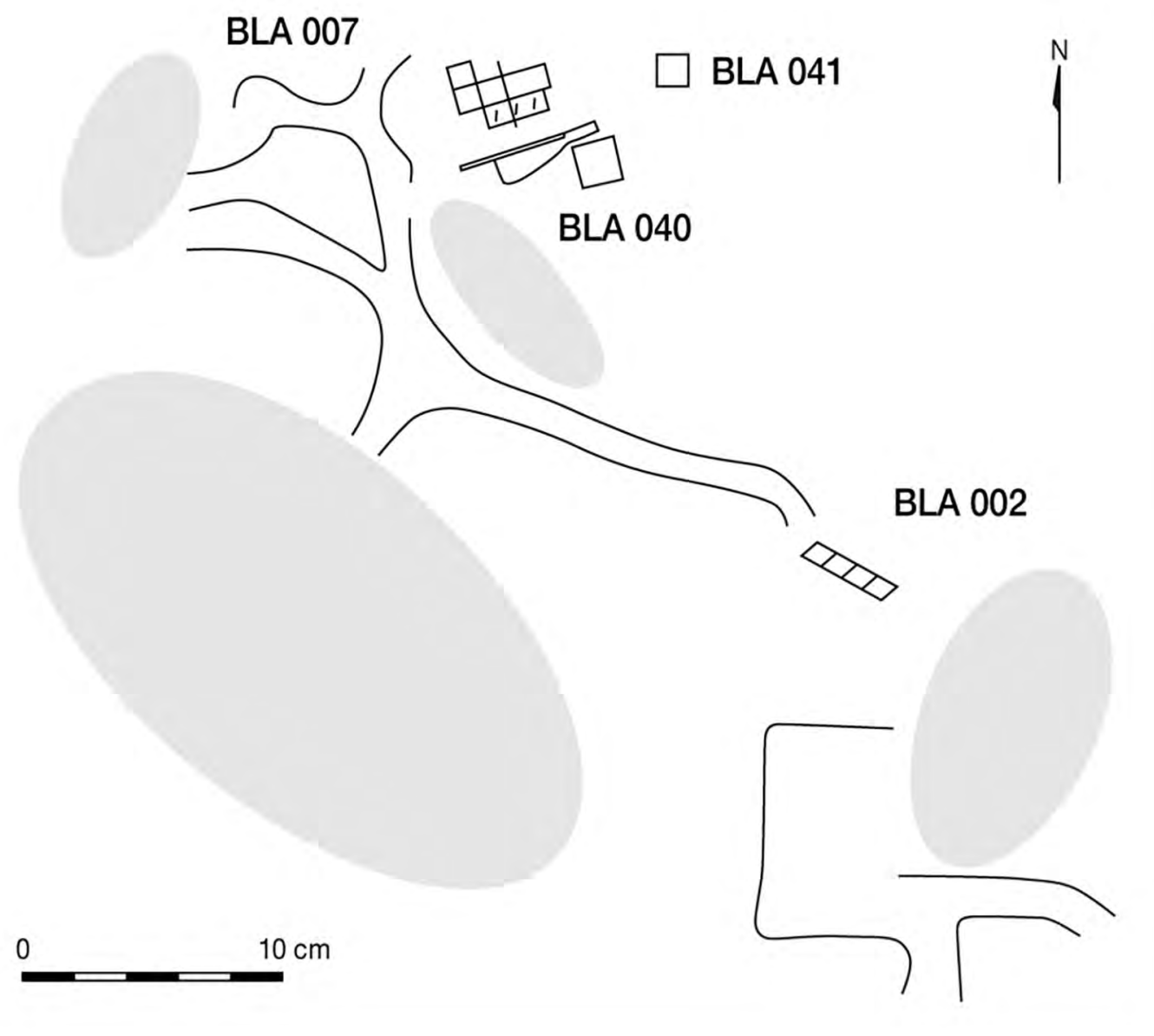

Figure 12.4. Site map of excavated areas, pathways (indicated by black lines) and compacted areas (grey ovals).

Source: Danielle Kelly, Rentia Ouzman and ANU CartoGIS.

\section{Finds and features}

Perhaps counterintuitively for an army camp-or at least for a substantial habitation area as suggested by the features reported on below (pathway, toilet/ablution block, laundry/shower, septic tank and borehole) - we found very few artefacts not linked to the construction of these features. These few artefacts are largely undiagnostic in both material and form (Table 12.1 and Figure 12.5). In addition to the expected finds of glass (bottles, windowpanes and a possible light bulb), ceramic (mostly plates and cups), metal (nails, wire, barbed wire, large and small bolts, two D-sized batteries), wood (jarrah construction timbers) and brick (with diagnostic examples from the Cardup factory), we also found many asbestos fragments, porcelain toilet bowl fragments and also brown stoneware sewage pipe sections. Other finds included a large chunk of anthracite, a possible bakelite clothing button, burned bone, a heavy-duty flat piece of 
fibre or card, charcoal, a small bottle stopper fragment made of stoneware (14 mm diameter), a strip of lead, and a possible toothpaste tube. We now turn to a discussion of each of the five features we investigated, as well as our test pitting program, to place these finds in context.

Table 12.1. Summary artefact table from excavations at Walliabup (Bibra Lake).

\begin{tabular}{|c|c|c|c|}
\hline Material & Artefact type & Area(s) found & Notes \\
\hline Asbestos & $\begin{array}{l}\text { Fragments of asbestos } \\
\text { wall and roofing }\end{array}$ & $\begin{array}{l}\text { BLA } 007 \text { A1, B1 and B3 all in } \\
\text { XUs [XU = excavation units] } \\
\text { BLA } 041 \text { (Septic tank) }\end{array}$ & $\begin{array}{l}\text { Approx. 50-100 small pieces } \\
\text { found in BLA007-not } \\
\text { cleaned. } \\
\text { Seven large pieces found } \\
\text { in BLA041-two painted } \\
\text { greenish colour (possible } \\
\text { camouflage). }\end{array}$ \\
\hline Bakelite & $\begin{array}{l}\text { Small bakelite clothing } \\
\text { button }\end{array}$ & BLA 002 A2 XU2 & $\begin{array}{l}\text { Beige-coloured clothing } \\
\text { button with two holes. } \\
\text { Diameter } 11.1 \mathrm{~mm} \text {. }\end{array}$ \\
\hline $\begin{array}{l}\text { Ceramic } \\
\text { (porcelain) }\end{array}$ & $\begin{array}{l}\text { Broken fragments } \\
\text { of three toilet bowls }\end{array}$ & BLA 007 B1-4 in all XUs, A1 & $\begin{array}{l}\text { Approx. 300-350 pieces of } \\
\text { white broken toilet bowl. }\end{array}$ \\
\hline $\begin{array}{l}\text { Ceramic } \\
\text { (stoneware pipe) }\end{array}$ & $\begin{array}{l}\text { Broken fragments } \\
\text { of stoneware pipe }\end{array}$ & $\begin{array}{l}\text { BLA } 007 \text { B1-4 in all XUs } \\
\text { BLA } 041 \text { (Septic tank) }\end{array}$ & $\begin{array}{l}\text { Approx. } 30-50 \text { pieces of } \\
\text { brown stoneware pipe; some } \\
\text { pieces with engraved maker's } \\
\text { marks. }\end{array}$ \\
\hline Charcoal & $\begin{array}{l}\text { Small pieces of } \\
\text { charcoal, including } \\
\text { that of the native } \\
\text { Zamia palm }\end{array}$ & $\begin{array}{l}\text { BLA } 002 \text { A1-4 } \\
\text { BLA } 007 \text { B1-4, C4 } \\
\text { Test pits (BLA 013, -021, -042) }\end{array}$ & $\begin{array}{l}\text { Samples retained from most } \\
\text { areas-significant amount } \\
\text { discarded; presumed large } \\
\text { burning event. }\end{array}$ \\
\hline $\begin{array}{l}\text { Concrete/stone/ } \\
\text { gravel }\end{array}$ & $\begin{array}{l}\text { Fragments of concrete, } \\
\text { gravel/concrete/ } \\
\text { limestone }\end{array}$ & $\begin{array}{l}\text { BLA } 002 \text { A1-2 } \\
\text { BLA } 007 \text { B1-3, C4 } \\
\text { Test Pits (BLA 013, -016, -042, } \\
-045)\end{array}$ & $\begin{array}{l}\text { Small fragments found } \\
\text { in abundance-samples } \\
\text { retained from most areas, } \\
\text { significant amount discarded. }\end{array}$ \\
\hline Glass (bottle) & $\begin{array}{l}\text { Small, brown, } \\
\text { rectangular glass } \\
\text { bottle }\end{array}$ & BLA 041 (Septic tank) & $\begin{array}{l}142.7 \mathrm{~mm} \text { (height) x } 57.3 \mathrm{~mm} \\
\text { (base diameter), 'F3 } 864 \mathrm{D} \text { ' } \\
\text { (on bottom). }\end{array}$ \\
\hline $\begin{array}{l}\text { Glass } \\
\text { (fragments) }\end{array}$ & $\begin{array}{l}\text { Fragments of varying } \\
\text { colours }\end{array}$ & $\begin{array}{l}\text { BLA } 002 \text { A1-3 } \\
\text { Test pits (BLA 016, -018, -021) }\end{array}$ & $\begin{array}{l}\text { Glass fragments, mostly } \\
\text { small, ranging from brown } \\
\text { to colourless. Predominately } \\
\text { found on surface levels. }\end{array}$ \\
\hline Glass (jar) & $\begin{array}{l}\text { Average-sized brown } \\
\text { glass jar }\end{array}$ & BLA 041 (Septic tank) & $\begin{array}{l}\text { ‘F20 H37 E 5’ (on bottom) } \\
\text { Hemingray Co. Factory } 37 \text {; } \\
\text { preserve or jam jar; } 110.7 \mathrm{~mm} \\
\text { (height) x } 75 \mathrm{~mm} \text { (base } \\
\text { diameter) x } 65 \mathrm{~mm} \text { (opening } \\
\text { diameter). }\end{array}$ \\
\hline Metal (assorted) & $\begin{array}{l}\text { Barbed wire, battery, } \\
\text { bolts, bottle cap, lead } \\
\text { off-cuts }\end{array}$ & $\begin{array}{l}\text { BLA } 007 \text { B2 } \\
\text { BLA } 040 \text { (Shower block) } \\
\text { Test pits (BLA 013, -016, -042) }\end{array}$ & $\begin{array}{l}\text { Various types of metal } \\
\text { pertaining to different uses; } \\
\text { most corroded and/or broken. }\end{array}$ \\
\hline $\begin{array}{l}\text { Metal } \\
\text { (fragments) }\end{array}$ & $\begin{array}{l}\text { Fragmented sheet } \\
\text { metal }\end{array}$ & $\begin{array}{l}\text { BLA } 002 \text { A2 and A4 } \\
\text { BLA } 007 \text { A1 and B3 } \\
\text { BLA } 040 \text { (Shower block) }\end{array}$ & $\begin{array}{l}\text { Small pieces significantly } \\
\text { corroded, easily broken. }\end{array}$ \\
\hline Metal (nails) & $\begin{array}{l}\text { Asbestos clout nails } \\
\text { and wood nails }\end{array}$ & $\begin{array}{l}\text { BLA } 002 \text { A2 and A4 } \\
\text { BLA } 007 \text { A1, B1-3, C4 } \\
\text { BLA } 040 \text { (Shower block) } \\
\text { BLA } 042 \text { (Test pit) }\end{array}$ & $\begin{array}{l}19 \text { nails with varying levels } \\
\text { of corrosion, depending on } \\
\text { location; predominately found } \\
\text { in association with walls. } \\
\text { Average } 26 \times 7 \mathrm{~mm} \text {. }\end{array}$ \\
\hline Wood & Human-modified wood & $\begin{array}{l}\text { BLA } 002 \text { A2 } \\
\text { BLA } 007 \text { B4 } \\
\text { Test pits (BLA 021, -042) }\end{array}$ & $\begin{array}{l}\text { Nine pieces of dark red/ } \\
\text { brown wood of varying sizes. }\end{array}$ \\
\hline
\end{tabular}

Source: ARCY3002 class and Sven Ouzman. 

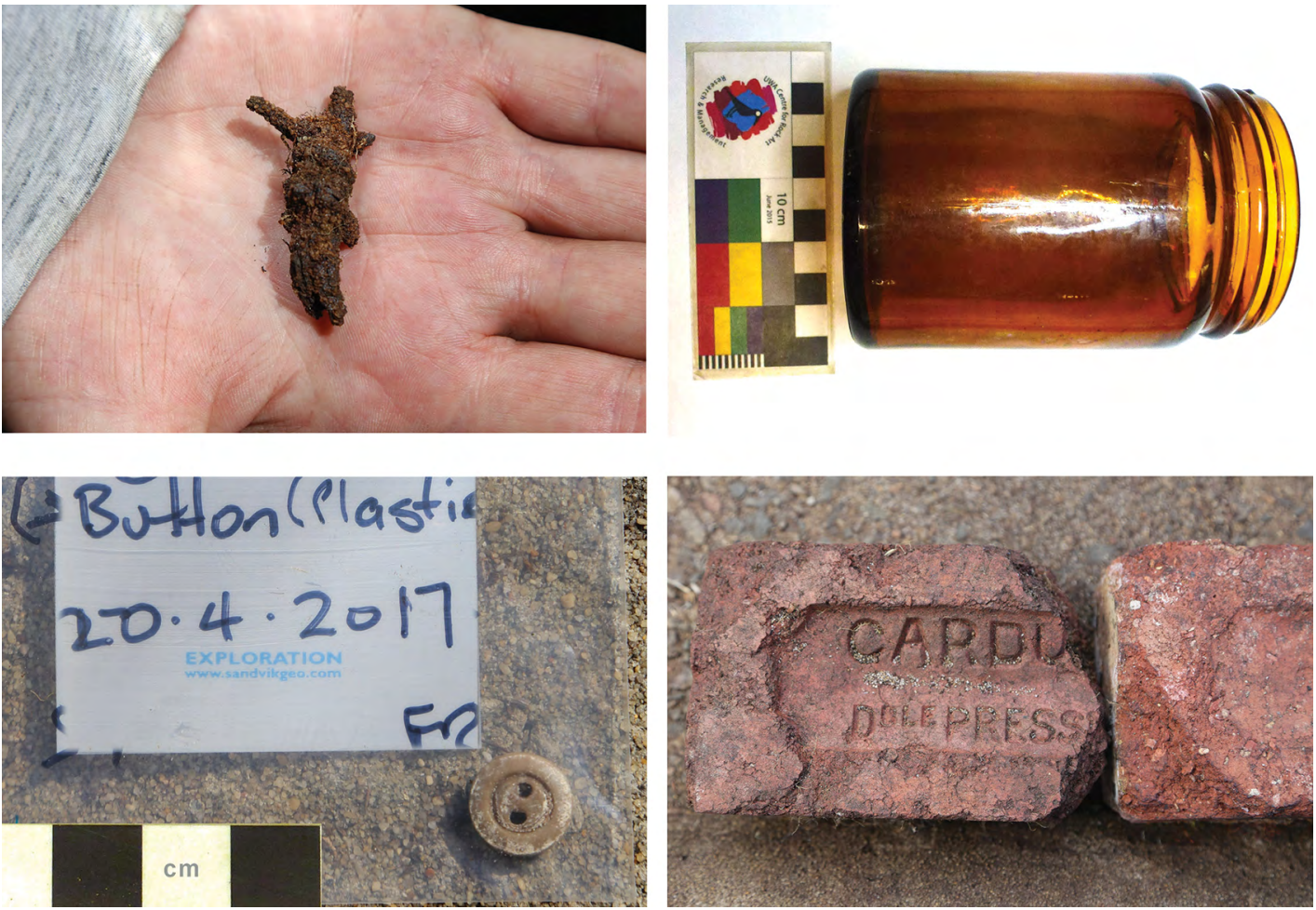

Figure 12.5. Selected finds from excavations at Walliabup (Bibra Lake).

Clockwise from top left: barbed wire, bottle, Cardup brick, ?military button.

Source: Sven Ouzman.

\section{BLA 002 (pathway or road)}

Almost no artefacts were recovered from this putative pathway or road (Figure 12.6 for plan and section diagrams). In total, we had $<20$ artefacts in the form of glass fragments, a heavily corroded circular $10 \mathrm{~cm}$ diameter metal object, a brick with 'Cardup B+H Press' stamped into the frog (depressed area of the brick), plastic fragments, fibreboard, porcelain fragments and the head of a nail. Yet despite this paucity of artefacts, one of our most diagnostic artefacts came from BLA 002 in the form of a khaki-coloured plastic (possibly bakelite) button that was possibly from a military uniform (Figure 12.5). While the finds were few, the pathways were substantial and required tonnes of crushed limestone; probably for narrow roads for army trucks, and/or paths to a parade ground (see the larger ovoid hardstanding areas shown in Figure 12.4). $\mathrm{pH}$ readings varied from neutral to alkaline. 


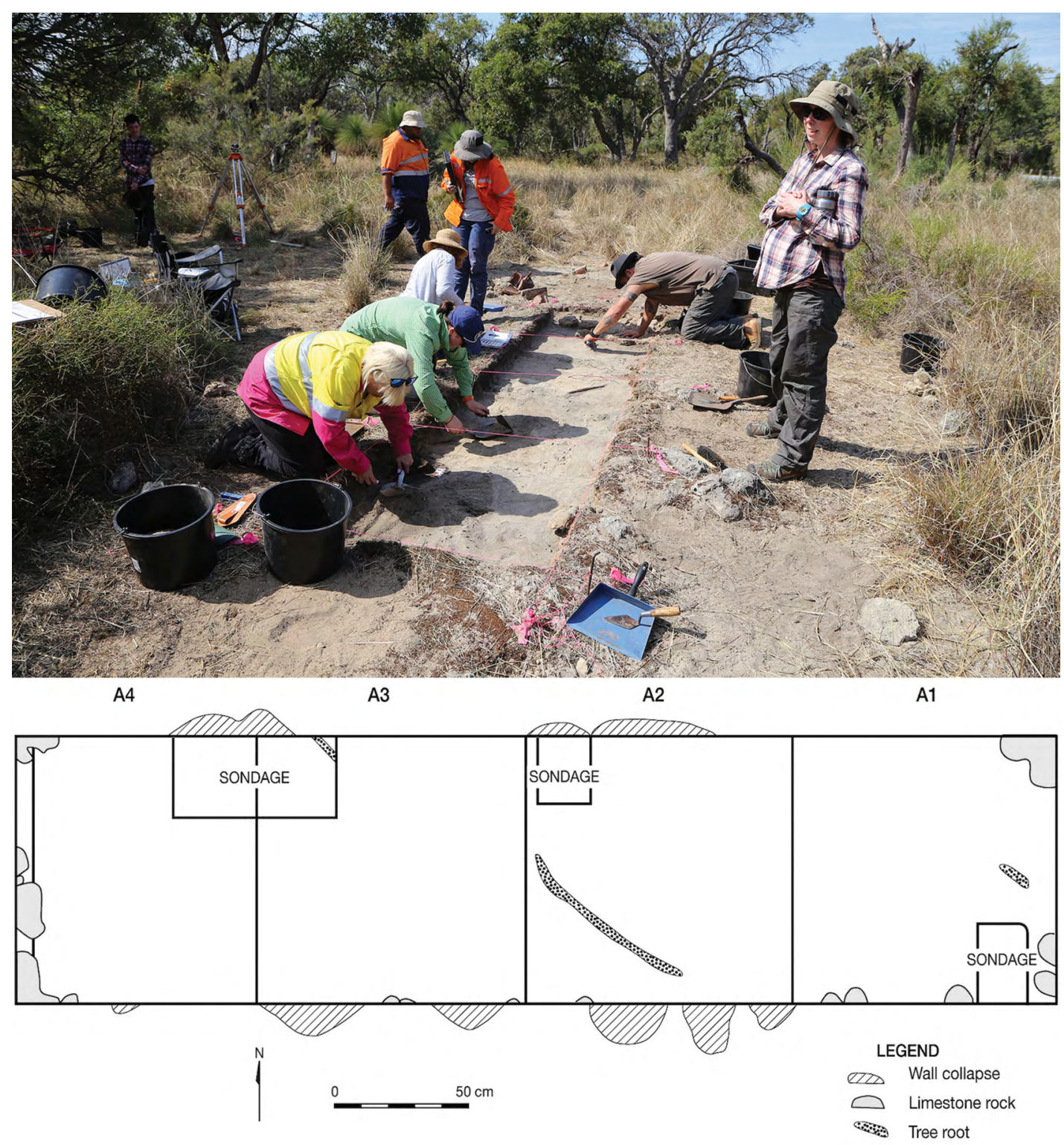

SOUTH EAST

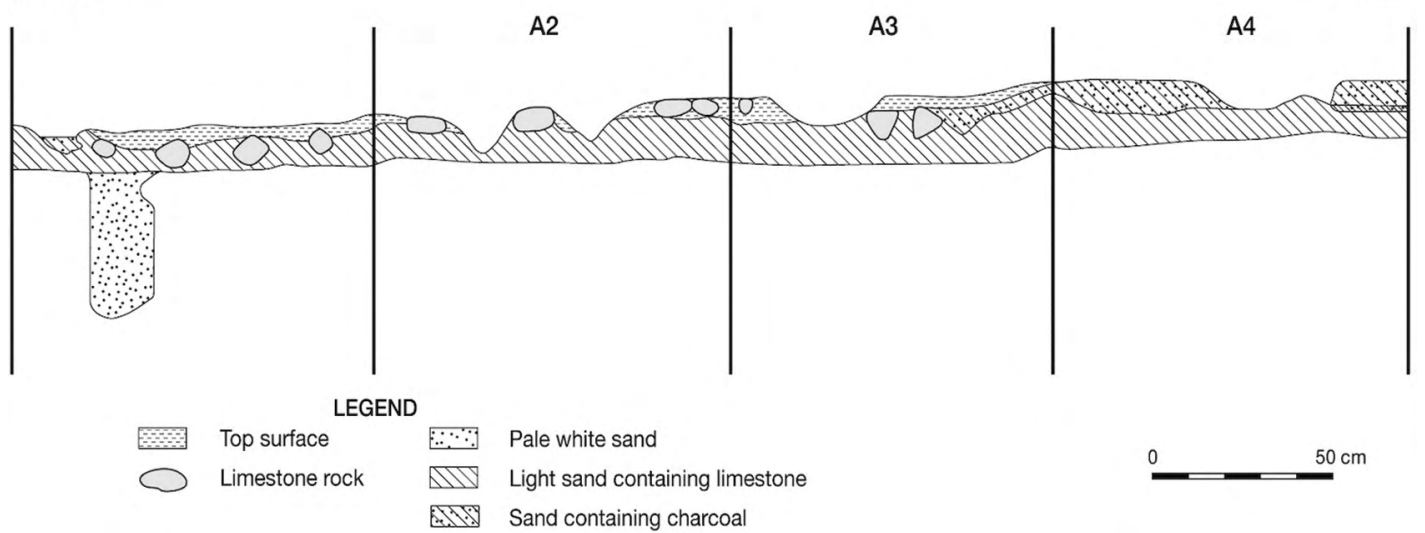

Figure 12.6. General aspect, plan and section of BLA 002 (pathway) excavation.

Source: Sven Ouzman (photo); ARCY3002 class (drawings); ANU CartoGIS (digitisation of plan and section). 


\section{BLA 007 (toilet block)}

Approximately $65 \mathrm{~m}$ north-west of the pathway excavation, we made a $2 \times 1 \mathrm{~m}$ concrete base our focus (Figure 12.7). It had three raised sections supporting porcelain toilet bases, each in front of a vertical brown clay sewage pipe. Many pieces of sewage pipe were lying on the surface to the south within $2 \mathrm{~m}$ from the toilet block. Four approximately $40 \times 40 \mathrm{~cm}$ concrete paving slabs were found approximately $75 \mathrm{~cm}$ in front (north) of the toilets, with concreted brick wall coursing plus repurposed concrete chunks forming a wall/structure to the north-west. A second $2 \times 1 \mathrm{~m}$ trench was opened to investigate this feature, which may have been a room that had been inexpertly added or modified at some point; possibly to add a toilet/changing area. Artefacts recovered included clouting nails, flat asbestos fragments, porcelain fragments, a posthole, concrete slabs, sewage pipe sections and a piece of anthracite. $\mathrm{pH}$ readings varied from 6 to 7.

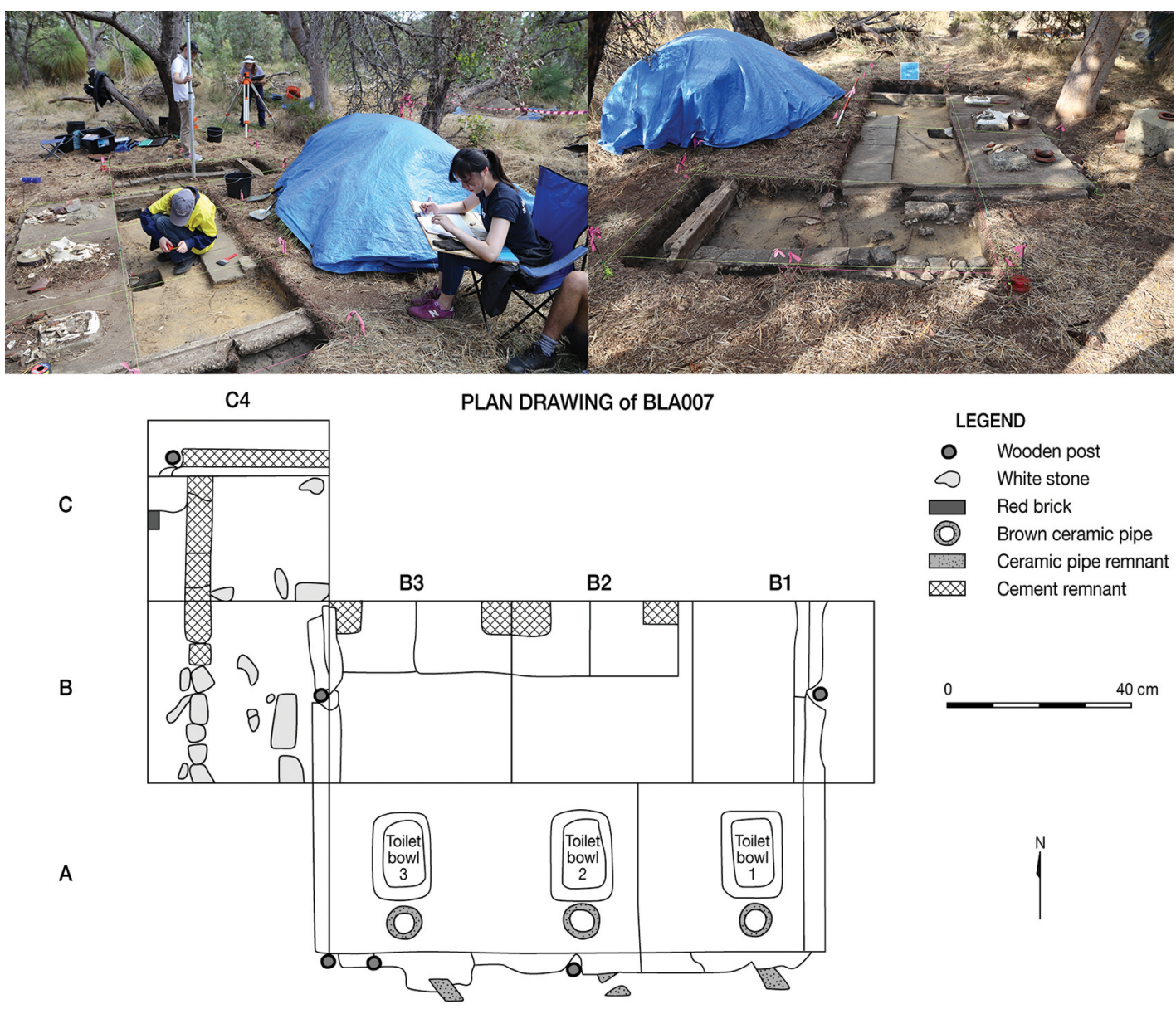

SECTION DRAWING of BLA007

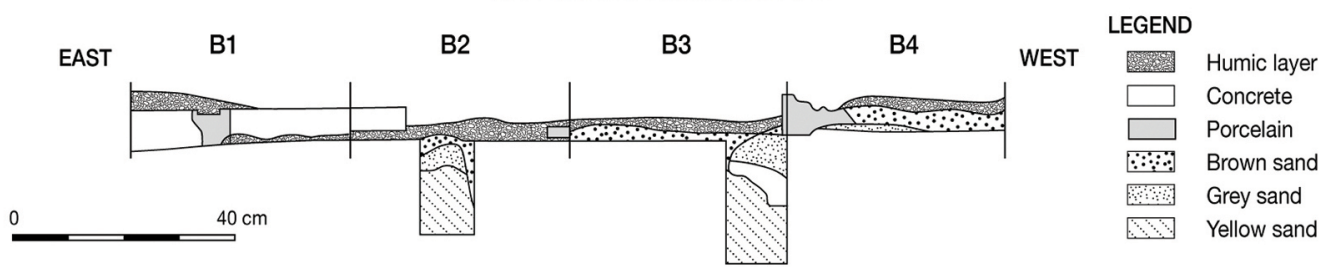

Figure 12.7. General aspect, plan and section of BLA 007 (toilet block) excavation. Blue tarpaulin protecting large grass tree (Xanthorrhoea sp.).

Source: Sven Ouzman (photos); ARCY3002 class (drawings); ANU CartoGIS (digitisation of plan and section). 


\section{BLA 040 (laundry or ablution block)}

Located c. $3 \mathrm{~m}$ south (behind) of the toilet block, this substantial structure (Figure 12.8) had a concrete drainage channel and series of paving slabs leading up to it and a larger $25 \mathrm{~cm}$ deep concrete trough associated with it. Interestingly, the lowest (and only) brick coursing directly on the concrete pad evinced torque breakage, supporting the auction notice's contention that building material was scarce (cf. Figure 12.2). The site appeared cleaned-with some vigour. Indeed, almost all above-ground materials were removed_even if they had been nailed/bolted/ concreted in place, providing some evidence of post-war scarcity and hardship. This structure also had short $(\mathrm{c} .12 \mathrm{~cm})$ metal rods protruding from the lowest concrete coursing — of the kind often used to support asbestos walling in shower blocks or laundries. Indeed, tens of fragments of asbestos were recovered from the surface and near surface and placed in Ziploc bags and buckets of water to ensure safety of excavators. Finds included one complete and two partial D-sized batteries, a corroded metal button (possibly brass, and $14 \mathrm{~mm}$ in diameter), a metal bottle cap, two metal bolts ( $91 \mathrm{~mm}$ and $131 \mathrm{~mm}$ long, $13 \mathrm{~mm}$ diameter), 12 metal fragments, six round nails (27-56 mm long), five bricks marked 'CARDUP EXPRESS' and glass bottles, including two with the markings 'F3 864 D' and 'F20 H37 E 5' on their bases. Out of interest, a few metres east of this feature is a substantial tree with marked diagonal scarring on three sides of its base, which we interpret as the tree being used as a holdfast for a cable that stabilised a water tank, which would have been needed for the toilets and possible laundry. $\mathrm{pH}$ readings were 7 in the slab area and 6 in the drainage/trough area.

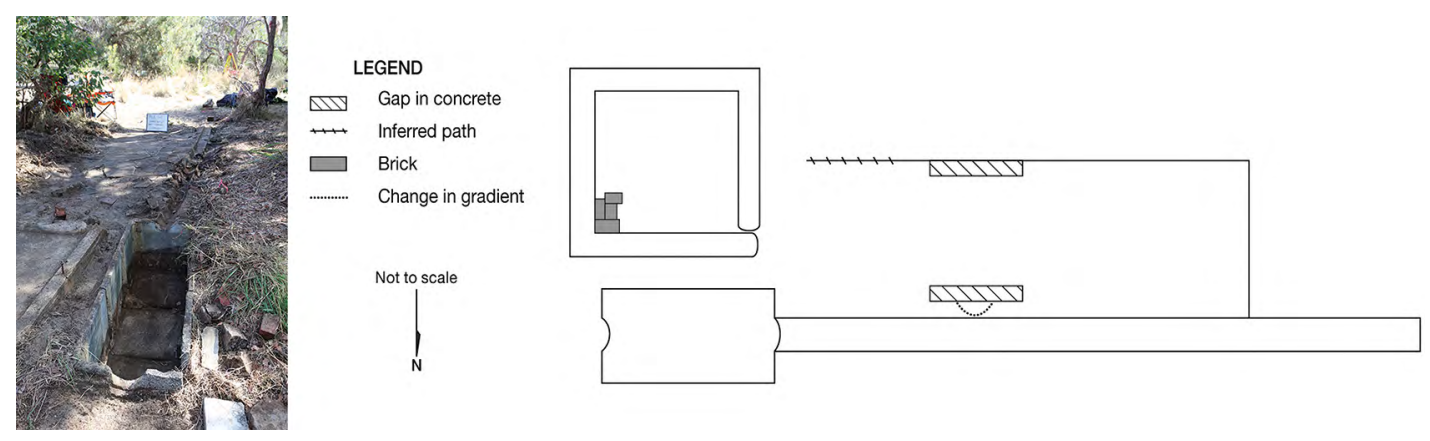

Figure 12.8. General aspect and plan of BLA 040 (?laundry) clearance.

Note concrete water channel and trough and remnant metal rods.

Source: Sven Ouzman (photos); ARCY3002 Class (drawings); ANU CartoGIS (digitisation of plan).

\section{BLA 041 (septic tank)}

Approximately $4 \mathrm{~m}$ south-east of the toilet block was a $2.0 \times 1.5 \mathrm{~m}$ concrete slab in two parts covering a $1.5 \mathrm{~m}$ deep brick and concrete septic tank (Figure 12.9). Approximately 680 litres of water was bailed out and a long-necked tortoise was removed (the tortoise was taken to the nearby Native Ark), revealing a collection of over 50 artefacts. These included intact glassware of all descriptions, jarrah timber planks with a dark green enamel paint, asbestos fragments, 14 bricks, clay sewer pipe sections/fragments and toilet porcelain fragments. 


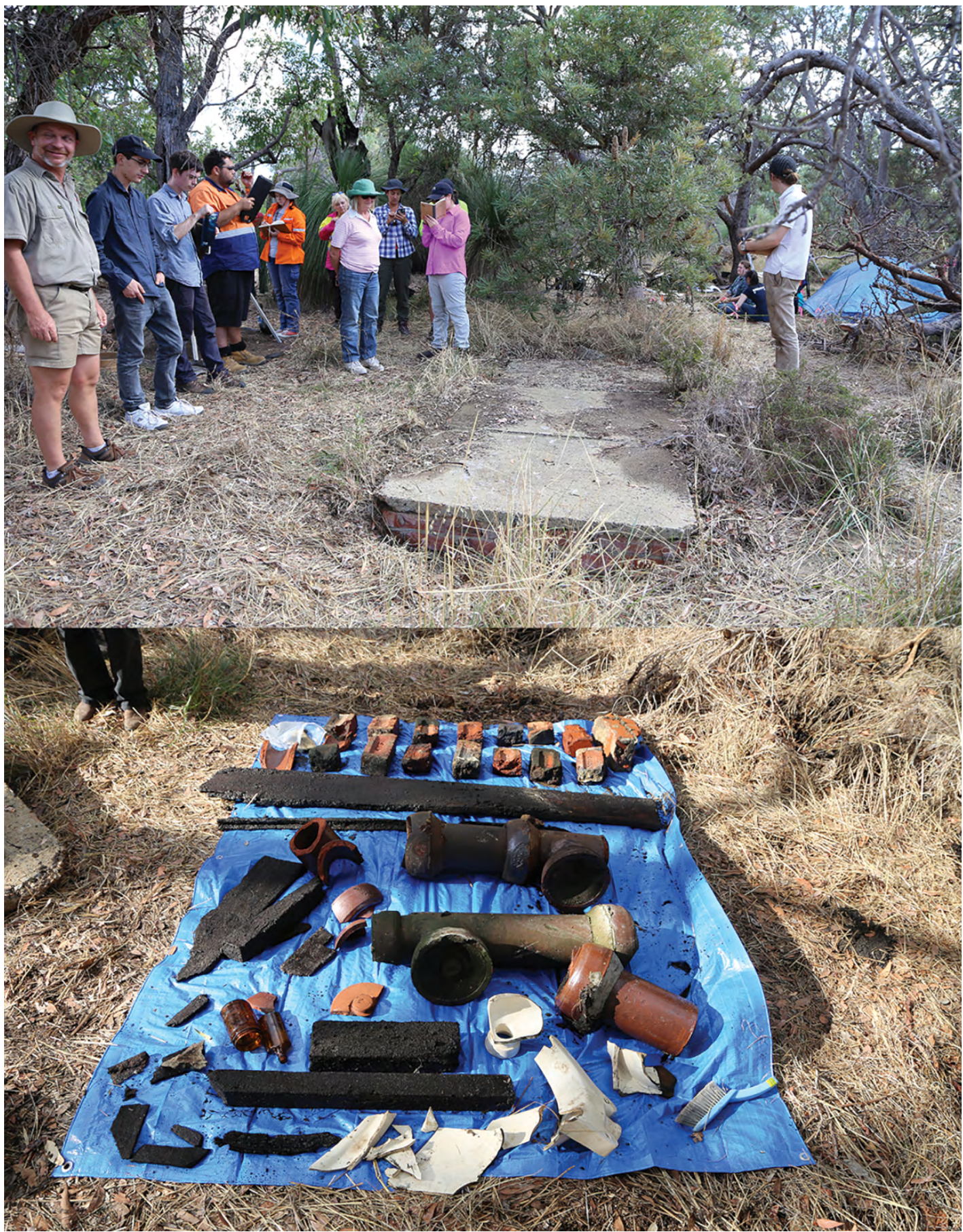

Figure 12.9. BLA 041 (septic tank) and finds.

Source: Sven Ouzman.

\section{BLA (concrete pad and borehole)}

No artefacts bar chunks of concrete and some rusted metal sheeting were recovered from surface clearing, but the pad had clear footings, inset wooden sleepers/supports, and a vertical metal pipe (Figure 12.10). We interpret this as the site of the 2000-gallon water tank listed in the auction notice (Figure 12.2), which may have required a diesel pump, likely mounted on wooden supports to mitigate vibrations. 


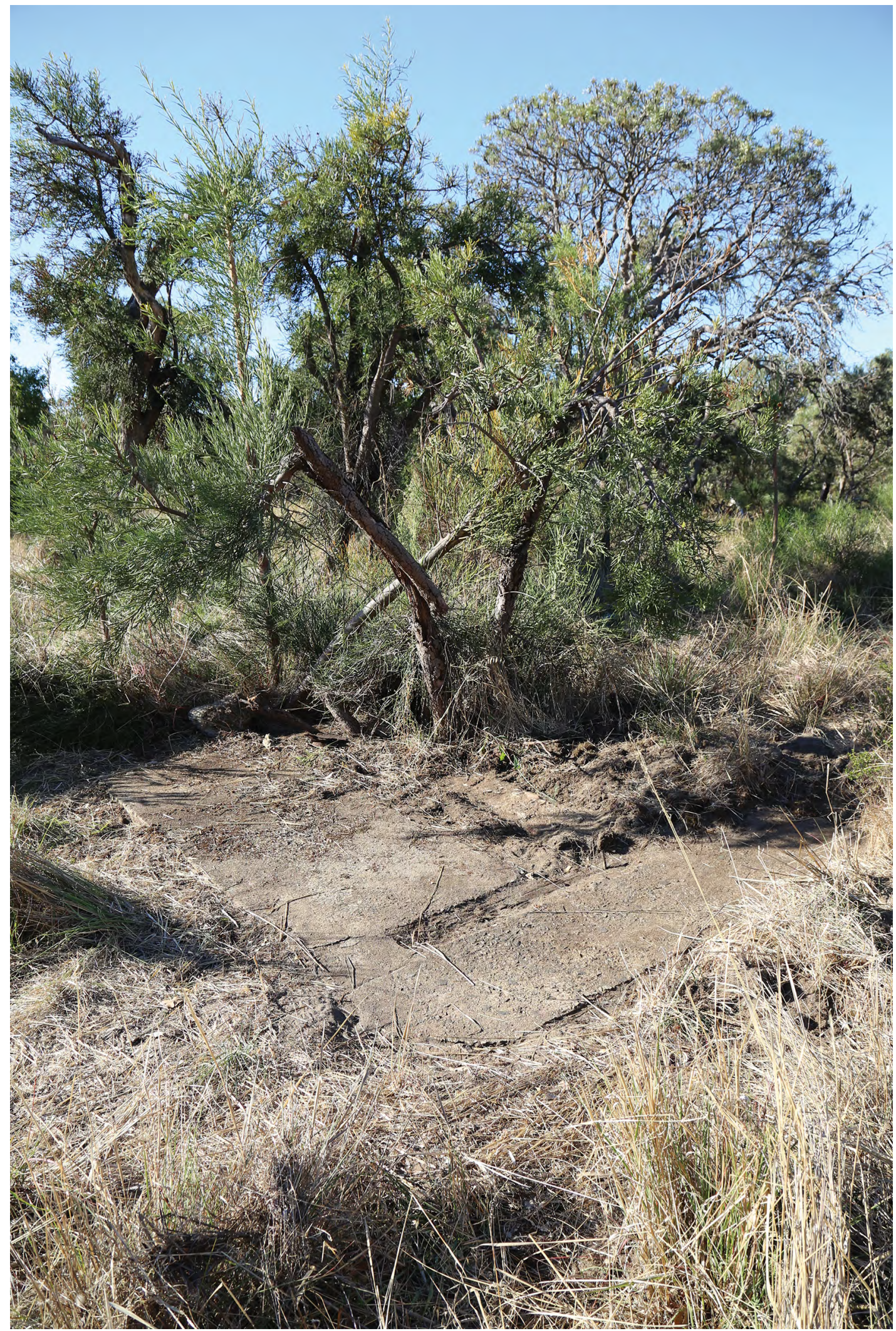

Figure 12.10. Concrete pad, inset wooden supports and borehole.

Source: Sven Ouzman. 


\section{Shovel test pitting}

Our final set of activities focused on metal detector-identified areas of interest. We found little material-mostly metal fragments in the form of barbed wire and nails, with some glass fragments and large quantities of scattered charcoal (the bushland burns regularly). The glass fragments ranged from the very thin (probable light bulbs) to very thick (probable truck lights or similar; different from bottle bases). The so-called 'bunker' depression had barbed wire but no other finds on the surface and we did not excavate this feature because it would take more time than we had available.

\section{Making sense of the artefactual evidence}

No single artefact or feature unequivocally resolves the issue of which one or combination of the three army units were camped here-if any. Indeed, most of the artefacts are what one could expect from a school (the original school is only a few hundred metres away), agricultural business or similar institution. Some artefacts are tantalising. The green 'camouflage' paint on the jarrah timbers from the septic tank; the quasi-military button from the pathway excavations, and the ubiquitous barbed wire finds would not be out of place in a military camp-but neither would they be unique to it. Turning to dating, many artefacts are from the right time period. For example, Cardup bricks with the markings we found were made between 1926 and 1942, when production halted because of World War II, only to resume again in 1954 with a different set of markings (Cardup then closed in 2012 and reopened in 2018 as Austral Bricks) (Department of Planning, Lands and Heritage 2000; Western Australian Museum n.d.; for brick dating see Stuart 2005). One glass bottle from the septic tank has tentatively been identified as a preserve or jam jar (Figure 12.5), possibly from the Hemingray Company, who were better known for making glass insulators (Whitten 2015). The considerable effort put into the pathways - with limestone that would have been brought from the coast on trucks and extensive paths/roads made-suggests an order, structure and availability of labour beyond the means of a farm, school or similar. Indeed, when writing about the Attadale camp of the 55th Searchlight Battery, Tucker reports that 'the battery was a special tented area with gravelled paths between tent lines' (1991:65). The recurrent asbestos finds suggest extensive use of prefabricated structures, which also suggest an institutional rather than a domestic use. But while there is no individual, definitive martial material or artefact, we also need to consider these artefacts and structures in volume and in aggregate. What other use would explain this spatial layout, dearth of artefacts and substantial infrastructure? A military use and subsequent auction is certainly more likely than almost any other scenario. Indeed, it is unusual to have such an investment in infrastructure which is then almost completely removed. The short period of occupation plus military emphasis on cleanliness may also help explain the dearth of artefacts. Finally, the information from the auction notice about the near-complete removal of the SL Bty's artefacts and features raises the question of how we deal with the systematic absence of evidence where the majority of a site is sold off and used at multiple other sites for non-war purposes.

\section{Beyond the finds and features and back to nature for the (eco)facts}

We did, however come across one off-site artefact type that (almost) provides definitive evidence of an AWAS presence. This is in the form of two photographs that Private Margaret May Robertson (Royal Australian Signal Corps) took on 1 January 1944 that show AWAS personnel posing in front of a fallen jarrah tree (Eucalyptus marginata) with a distinctive bend in it (Figure 12.11). 
Thanks to jarrah's legendary resistance to termites, we were able to re-locate this tree, definitively establishing an AWAS presence on the site. Of course, this presence could have been a visit by AWAS personnel and not a permanent camp, but photos from the same collection show tents, substantial structures and a rather disconcerting image of a man with a large knife at the quartermaster's store (Figure 12.12; see also Tucker 1991:99 for male and female personnel at '66 AA Battery Bibra Lake').
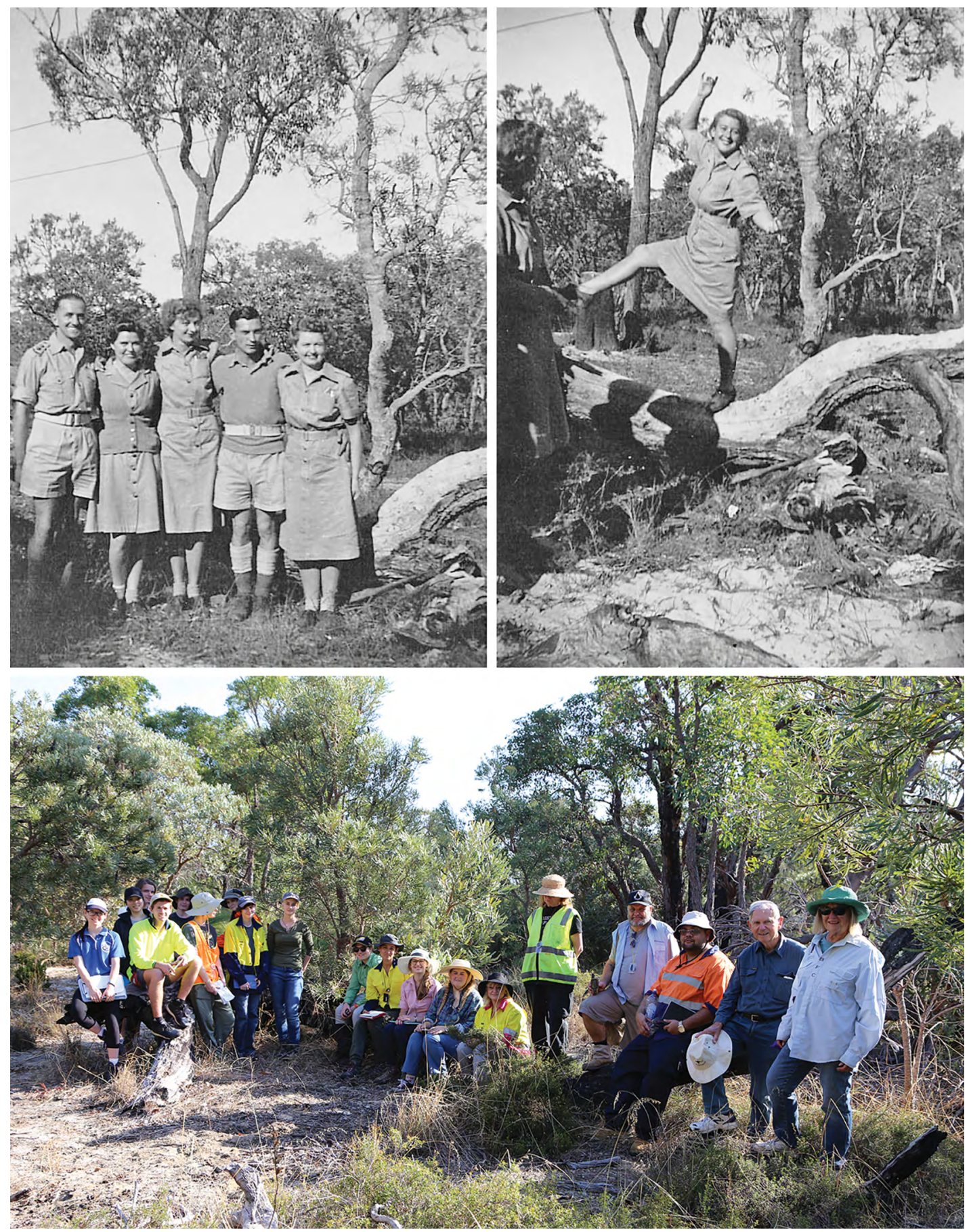

Figure 12.11. Photographs of AWAS personnel at distinctive jarrah tree, Walliabup (Bibra Lake), 1 January 1944.

Bottom photograph of fieldschool participants on the same tree, 73 years later.

Source: (Top) Private Margaret May Robertson, provided by her daughter Kaye McNally. (Bottom) Sven Ouzman. 


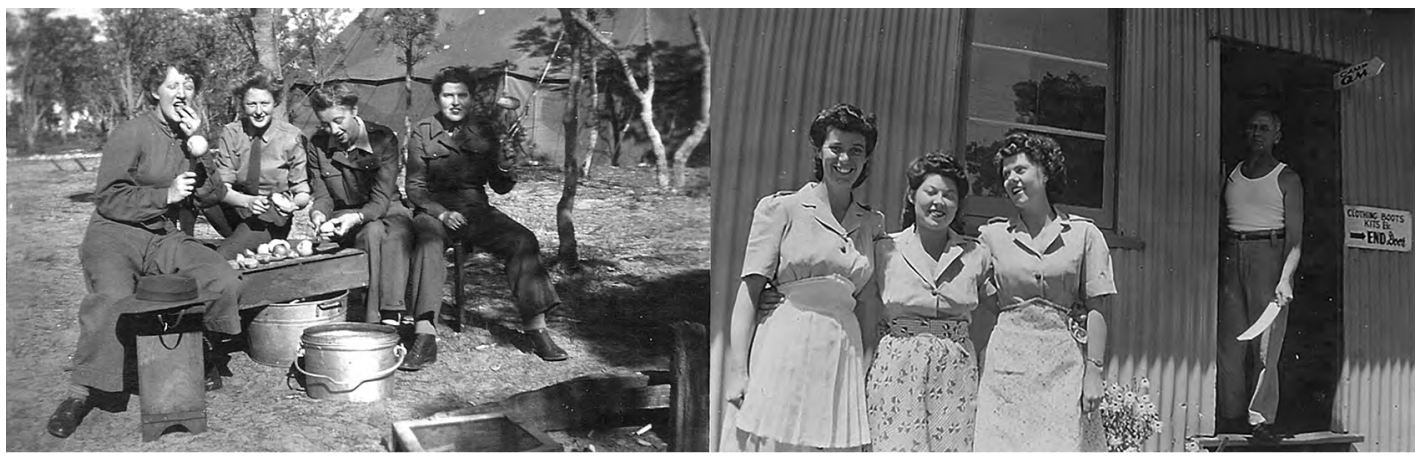

Figure 12.12. Photographs of AWAS personnel, Walliabup (Bibra Lake).

Source: Private Margaret May Robertson, provided by her daughter Kaye McNally.

\section{Discussion: The archaeology of war and of women at war}

These photographs provide valuable glimpses of daily life as well as details of material culture, uniforms and terrain. The photographs are, however, posed and belie the very real anxiety the people of Perth experienced during war. Though never a major combat arena, for a considerable time people in Western Australia thought it might be, resulting in an extensive defensive military infrastructure that ran from the north-west's telegraph, observation and radar stations, radar outposts, airfields and ammunitions dumps, to Fortress Fremantle, and to regional and southern Western Australia (cf. Bowman 2016). Actions such as the 1941 sinking of Australia's HMAS Sydney II (only rediscovered in 2008) by the German ship Kormoran, the eventual 1942 sinking of the MV Koolama in Wydham, the 1942 and 1943 Japanese air attacks on Broome and Kalumburu, plus two Western Australian emergencies in 1942 and 1944 for a forecast sea invasion of the coast and especially Fremantle Port (see Cairns 2011), created a very uncertain and anxious atmosphere. A similar situation is documented in Martin Wimmer's (2014) study of air raid shelters and associated structures in Adelaide, South Australia, where there was a similar fear of imminent aerial bombardment and invasion by sea. This widespread atmosphere of terror and preparation is hard to properly understand almost 80 years later dealing with inert archival and archaeological sources. Recorded oral testimonies provide some of this texture, though with more bias. Rather like Hannah Arendt's characterisation of evil as 'banal', a great deal of the archaeology of war is similarly quotidian to the point of being hard to distinguish from the material culture of the wider society at the time.

Archaeological 'ground-truthing' of military sites, especially short-lived ones, can be surprisingly equivocal, as our experience at Walliabup (Bibra Lake) shows. But multi-stranded archaeological investigation is sorely needed because we want a democratic discipline able to remember both the places history is forgetting and, especially, the people that populated these places. While all sources have their bias - from non-diagnostic artefacts, to biased archives to evolving oral testimonies - archaeology's strengths at dealing with multiple sources of evidence creates a mutually enabling and constraining web of evidence and argument that also helps humanise this past. At Walliabup (Bibra Lake) this humanising still has some way to go. For example, we struggle to gender places and artefacts, especially within the context of 'total institutions' such as the military. In addition, scholarship tends to be masculinist (see Garton 1998 for overview). So far, our contribution to understanding how 200 or more women, many of them far from home in an unfamiliar place, experienced the war, is modest (see Seitsonen et al. 2017 for work on the dislocation of military personnel). Basic information such as knowing where these women were 
stationed requires considerable effort to glean. Indeed, our reading of the Intelligence Summaries suggests Walliabup (Bibra Lake) may have been a temporary situation and even training location for many AWAS personnel, who were then redeployed to places like Wadjemup (Rottnest Island) as part of their considerable naval defences. The AWAS identity was also largely subsumed into that of the 66th Searchlight Battery and/or 116th Light Anti-Aircraft regiment.

These are serious challenges, as it is not just women who are under-represented in the master narratives of war. There are Indigenous people (e.g. Saunders 1995), children and immigrants to consider. For example, at Bibra Lake, Chinese market gardeners—and probably people of other ethnicities - enjoyed regular trade with the camp for fresh produce. We have one account where one such gardener's life was saved by AWAS personnel when he was caught alight during a bushfire (Tucker 1991:79). Also, Bibra Lake was home to many Italian immigrants, who were rounded up and sent to internment camps on Wadjemup (Rottnest Island) and elsewhere. Further, subaltern histories of LGBTIQ or differently abled people and the like could also be an important area for study, and incipient work in this regard has begun (e.g. Barrett 2007; Davila and Epstein 2020).

\section{Conclusion: The role of past colonial wars in a post-colonising society}

The AWAS 'signature' at Walliabup (Bibra Lake) has not been resolved by archaeology, but by primary off-site artefacts in the form of the auction notice and photographs from the time, as well as first-person testimony from Eileen Tucker. Had we worked in different areas-such as to the west where there are more roads and metal scatters, we may, for example, have located the camp midden, which would contain diagnostic artefacts. Or we could have worked south of Hope Road, where we have unsubstantiated reports of prefabricated living quarters for army personnel. Our frequent finds of asbestos support the statement that 'pre-fab huts were erected' at Walliabup (Bibra Lake) (Tucker 1991:65). It is almost certain where we worked was where the 66th Searchlight Battery was stationed, with AWAS support personnel. This does not mean archaeological fieldwork-which is costly and can be destructive-is of no use. Collating and synthesising information, while being able to calibrate spatial and temporal contexts from individual personnel to the wider arena of the world war, helps craft a more coherent, factrich and socially responsive narrative. At times, archaeology may be the only way to recover certain kinds of evidence. At the very least, archaeology provides another strand of evidence that allows for a convincing 'cabling' of evidence (cf. Wylie 2002). Also, the very activity of fieldwork is socially productive and engaging. Our activities, initiated by the Bibra Lakes Residents Association's invitation, literally brought people together (Figure 12.13). Dozens of visitors, local newspaper articles (e.g. Luff 2017), public talks and word-of-mouth created a 'public archaeology' (cf. Moshenka 2017). Importantly, our activities made people regard their backyard, so to speak, in a new light-and engage with an almost-forgotten history. This engagement has included independent public and municipal archival research and oral testimony work. For example, there is the very competent 'Bibra Lake AWAS Camp' Wikipedia entry (Wikipedia 2015-ongoing) and the Cockburn Libraries (2015) entry and work on the camp. The publication of books by AWAS personnel (Beveridge 1988; Desmond 1988; Oliff 1981; Tucker 1991) and increasing mentions via the web and social media (see also ARCY3002 2017) provide the much-needed detail and texture of lived experiences. Our work contributes to a still small-but-growing set of case studies on histories of war that are important to local communities (e.g. Burke et al. 2011), rather than being proclaimed as important by distant authoritative metanarratives. 


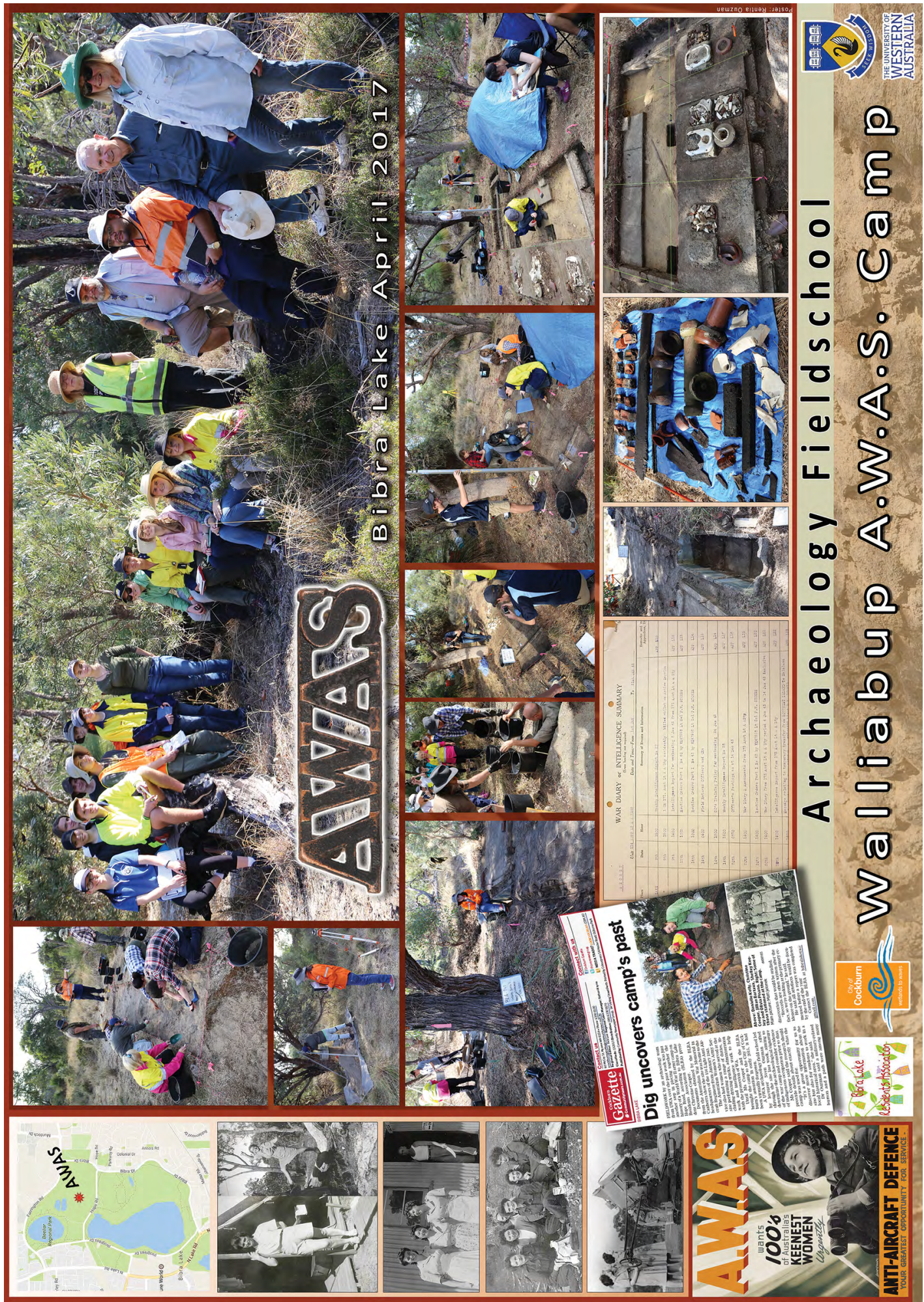

Figure 12.13. Community poster of 2017 AWAS archaeology fieldschool.

Source: Sven Ouzman. 
War archaeology is, however, often painful, with remembrances of death, violence, loss and subjugation to foreign powers (Moshenka 2006). But it can also be useful. Meskell and Scheermeyer (2008; see also Symonds 2019) write about archaeology and heritage as 'therapy'. Archaeology's often slow, methodical way of understanding the past helps people come to terms with difficult or occluded pasts in a slow, managed way. In Australia we have many unresolved issues of history, race, gender and war-with the militarisation of the present through distorted versions of national events like Anzac Day and the associated 'Anzackery' a prime example (Stephens 2015; see also Ouzman 2021). A war is, after all, a failure of humanity and communication, and results typically from the actions of a few powerful interests who do not bear the brunt of their decisions. Australia's participation in World War II is as much a colonial legacy as an action to fight against unjust and hostile actions. Scale is a key discriminant here as it is easy to lose sight of individual contributions and experiences of people who did have agency, but not in conditions of their choosing. The women of Walliabup (Bibra Lake) are no longer as invisible as they were, though much more work needs to be done to rehumanise their lives and contributions. But the outlook is positive and there is evidence of a more human, less jingoistic remembrance of this past at the Walliabup (Bibra Lake) site. In 2019, an inspection of the site to make sure our post-excavation rehabilitation was still in order came across a touching tribute to the women and men and others who had lived here in the latter half of World War II. This tribute took the form of a small wreath and private message of thanks that had been placed in a banksia tree at the toilet block site; showing that 'small things' are not always forgotten or, at the very least, can be re-remembered.

\section{Acknowledgements}

We acknowledge this work and chapter were undertaken on Whadjuk Nyungar land. We thank the City of Cockburn, Azelia Ley Museum, Bibra Lakes Residents Association and South West Aboriginal Land and Sea Council for their support of this project. We also thank the Cockburn Wetlands Centre and Native Ark for logistical support. We thank the UWA Archaeology Fieldschool class of 2017-Sophie Antulov, Victoria Bird, Alexander Burcham, Meg DrummondWilson, Jonty Franklin, Nicole Gan, Jessica Green, Emily Grey, Shelley Keeley, Danielle Kelly, Duane Kelly, Gary Nicol, Olivia Pisan, Fiona Reid, Matthew Tetlaw and Sarah-Jane Waters-for their physical and intellectual labour and acknowledge them as collective co-authors. We thank Rentia Ouzman and Jennifer Sheehan from the ANU College of Asia \& the Pacific, CartoGIS Services at The Australian National University for the digitisation of the sections, site plans and maps. We thank Beth Battrick for her meticulous copyediting. We thank Mirani Litster and Geoffrey Clark for their initiative in making this volume a reality, and for their kind and constructive comments on this chapter.

\section{References}

ARCY3002 2017. Bibra lake archaeology: Results from the 2017 ARCY3002 Field Methods undergraduate fieldschool at a possible AWS site, Bibra Lake. Unpublished collaborative student report. University of Western Australia, Perth.

Athena 1943. Front line girls: Work of the A.W.A.S. manning the searchlights. The Northern Times, 14 May. trove.nla.gov.au/newspaper/article/75135291.

Australian War Memorial 1943a. Unit war diaries, 1939-45 war. 116 Australian Light Anti-Aircraft Regiment (AIF), January-September 1943 (AWM52 4/11/11/6). AWM 2019.366.1548-1555. Australian War Memorial, Canberra. 
Australian War Memorial 1943b. Unit war diaries, 1939-45 war. 55 Australian Composite AntiAircraft Regiment, Royal Australian Regiment (Lower Establishment) October-December 1943 (AWM52 4/13/10/1). Australian War Memorial, Canberra.

Baker, F. 1988. History that hurts: Excavating 1933-1945. Archaeological Review from Cambridge 7(1):93-109.

Barrett, M. 2007. Subalterns at war. Interventions 9(3):451-474.

Beck, C., M. William Gray Johnson and J. Schofield (eds) 2002. Matériel culture: The archaeology of 20th century conflict. Routledge, London.

Beveridge, J. 1988. AWAS: Women making history. Boolarong Publications, Chevron Island.

Bowman, C. 2016. Forgotten Australian radar sites rediscovered. War History Online, 11 May. www. warhistoryonline.com/war-articles/forgotten-australian-radar-station-sites-rediscovered.html.

Bracknell, C. and I.L. Collard 2012. Beeliar Boodjar: An introduction to Aboriginal history in the City of Cockburn, Western Australia. Australian Aboriginal Studies 2012(1):86-91.

Burke, H., A. Gorman, K. Mayes and D. Renshaw. 2011. The heritage uncertainty principle: Excavating air raid shelters from the Second World War. In O. Katsiyuki and A. Matsuda (eds), New perspectives in global public archaeology, pp. 139-154. Springer, New York. doi.org/10.1007/978-1-4614-0341-8_11.

Burke, H., B. Barker, L. Wallis, S. Craig and M. Combo. 2020. Betwixt and between: Trauma, survival and the Aboriginal Troopers of the Queensland Native Mounted Police. Journal of Genocide Research 22(3):317-333. doi.org/10.1080/14623528.2020.1735147.

Cairns, L. 2011. Secret fleets: Fremantle’s World War II submarine base. Western Australian Museum, Welshpool, Western Australia.

Carman, J. 1997. Giving archaeology a moral voice. In J. Carman (ed.), Material harm: Archaeological studies of war and violence, pp. 220-239. Cruithne Press, Glasgow.

Carman, J. 2013. Archaeologies of conflict. Bloomsbury, New York.

Chambers, J. and P. Jennings. 2017. Roe 8: Perth's environmental flashpoint in the WA election. The Conversation, 9 March. theconversation.com/roe-8-perths-environmental-flashpoint-in-the-waelection-74155.

City of Cockburn 2017. WWII army camp, Bibra Lake (site). Local Government Inventory. 17 February. www.cockburn.wa.gov.au/getattachment/029e0f9c-f21b-428d-9a9b-66ca20550e75/ ECM_5576126_v1_Bibra-Lake-WWII-Army-Camp-pdf.aspx.

Clark, B.J. 2018. Artifacts, contested histories, and other archaeological hotspots. Historical Archaeology 52:544-552. doi.org/10.1007/s41636-018-0128-5.

Cockburn Libraries 2015. Bibra Lake AWAS camp. 28 September. www.cockburnlibraries.com.au/blog/ cockburn-history-bibra-lake-awas-camp/.

Davila, D. and E. Epstein 2020. Contemporary and pre-World War II Queer communities: An interdisciplinary inquiry via multimodal texts. English Journal 110(1):72-79.

Deetz, J. 1977. In small things forgotten: The archaeology of early American life. Anchor Press, New England.

Department of Planning, Lands and Heritage 2000. Brick kilns. inHerit database. inherit.stateheritage. wa.gov.au/Public/Inventory/PrintSingleRecord/f3df98af-3255-4924-8ffc-8852ae0b19bd. Accessed 12 November 2020. 
Department of Planning, Lands and Heritage 2020-2021. Aboriginal Heritage Inquiry System. www.dplh. wa.gov.au/ahis. Accessed 12 November 2020.

Desmond, M. (ed.) 1988. Backing up the boys: The Australian Women's Army Service and Albury army area. The Club, Bandiana, Victoria.

Drake, C. and S. Kenneally 1998. Recollections of the Beeliar Wetlands: Recollections of long-time local residents. City of Cockburn, Cockburn, Perth.

Dunn, P. 2015. Bibra Lake army camp, Bibra Lake, WA, in Australia during WWII. Australia at war. www.ozatwar.com/ausarmy/bibralakearmycamp.htm. Accessed 2 February 2021.

Garton, S. 1998. War and masculinity in twentieth century Australia. Journal of Australian Studies 22(56):86-95. doi.org/10.1080/14443059809387363.

Graves-Brown, P., R. Harrison and A. Piccini (eds) 2013. The Oxford handbook of the archaeology of the contemporary world. Oxford University Press, Oxford. doi.org/10.1093/oxfordhb/9780199602001. 013.010 .

Hallam, S. 1987. Coastal does not equal littoral. Australian Archaeology 25:10-29. doi.org/10.1080/031 22417.1987.12093122.

Heywood, A. 2009. Australian Women's Army Service (AWAS) (1941-1947). The Australian Women's Register. 12 June. www.womenaustralia.info/biogs/IMP0149b.htm.

Higgins, J. 2015. The ruins of Bibra Lake's history. Perth Freight Link Info Blog, 18 September. perthfreight link.blogspot.com/2015/09/the-ruins-of-bibra-lakes-history.html.

Hook, F. and J. Dortch. 2017. Archaeology in the age of alternative facts: Archaeological investigations and Roe 8. In A. Gaynor, P. Newman and P. Jennings (eds), Never again: Reflections on environmental responsibility after Roe 8, pp. 107-117. UWA Publishing, Perth.

Luff, B. 2017. UWA dig uncovers World War II camp on Hope Road in Bibra Lake. Cockburn Gazette, 24 April. www.perthnow.com.au/community-news/cockburn-gazette/uwa-dig-uncovers-world-war-iicamp-on-hope-road-in-bibra-lake-c-808284.

Lyon, R.M. 1833. A glance at the manners, and language of the Aboriginal inhabitants of Western Australia: With a short vocabulary. Perth Gazette and Western Australian Journal, 20 April.

Meskell, L. and C. Scheermeyer, 2008. Heritage as therapy: Set pieces from the New South Africa. Journal of Material Culture 13(2):153-157. doi.org/10.1177/1359183508090899.

Moshenska, G. 2006. Scales of memory in the archaeology of the Second World War. Papers from the Institute of Archaeology 17:58-68. doi.org/10.5334/pia.269.

Moshenska, G. (ed.) 2017. Key concepts in public archaeology. UCL Press, London.

Oliff, L. 1981. Women in khaki. Olli Publishing Company, Sydney.

Ouzman, S. 2021. Archaeologies of Austral: Australian identities from the Pleistocene to the Anthropocene. Journal of Australian Studies 45(2). doi.org/10.1080/14443058.2021.1910857.

Polglaze, R. 1986. The Aboriginal significance of Coolbellup/Walliabup wetlands (North Lake and Bibra Lake). Unpublished manuscript, Perth. Accessible from Azelia Ley Museum.

Pollard, T. and I. Banks 2005. Why a journal of conflict archaeology and why now? Journal of Conflict Archaeology 1(1):iii-vii. doi.org/10.1163/157407705774929024.

Saunders, K. 1995. Inequalities of sacrifice: Aboriginal and Torres Strait Islander labour in northern Australia during the Second World War. Labour History 69:131-148. doi.org/10.2307/27516395. 
Seitsonen, O., H. Vesa-Pekka, K. Nordqvist, A. Herva and S. Seitsonen 2017. A military camp in the middle of nowhere: Mobilities, dislocation and the archaeology of a Second World War German military base in Finnish Lapland. Journal of Conflict Archaeology 12(1):3-28. doi.org/10.1080/ 15740773.2017 .1389496$.

Sharp, J.L. 2002. Short histories of the 116th and 2/3rd Light Anti-aircraft Regiments. Australian War Memorial, Canberra.

Stephens, D. 2015. Anzac and Anzackery: Speech to Kogarah Historical Society, 14 May. Honest History, 9 June. honesthistory.net.au/wp/anzac-and-anzackery-kogarah-speech/.

Stuart, I. 2005. The analysis of bricks from archaeological sites in Australia. Australasian Historical Archaeology 23:79-88.

Sutherland, T. 2017. Battlefield archaeology: A guide to the archaeology of conflict. Bradford University Practical Guide Series 8. Bradford University, Bradford.

Symonds, J. 2019. Difficult pasts and haunted presents: Contemporary archaeology and conflict in an age of global uncertainty. Acta Universitatis Lodziensis. Folia Archaeologica 34:5-21. doi.org/10.18778/02086034.34 .01

Terra Rosa Consulting. 2016. Results of a historical and archaeological investigation of a World War II AWAS army camp located at Bibra Lake W.A. Unpublished report. Perth.

Tucker, E. 1991. We answered the call: AWAS of Western Australia and their mates. E. Tucker, Cloverdale.

Western Australian Museum n.d. Shipwreck databases. www.museum.wa.gov.au/maritime-archaeologydb/artefacts-debug?page=56\&order=field_site_area_code_value\&sort=asc\&ancods=\&id=\&fiel d_registration_number_value=\&name=\&filename. Accessed 5 November 2020 .

Whitten, D. 2015. Hemingray glass company. Glass bottle marks. glassbottlemarks.com/hemingray/. Accessed 3 September 2017.

Wikipedia 2015-ongoing. Bibra Lake AWAS camp. en.wikipedia.org/wiki/Bibra_Lake_AWAS_Camp. Accessed 25 January 2021.

Wimmer, M. 2014. Gimme shelter: Archaeology and the social history of structural defence in Adelaide 1941-1943. Unpublished PhD thesis. Flinders University, Adelaide.

Wylie, A. 2002. Thinking from things: Essays in the philosophy of archaeology. University of California Press, Berkley. 
This text is taken from Archaeological Perspectives on Conflict and Warfare in Australia and the Pacific, edited by Geoffrey Clark and Mirani Litster, published 2022 by ANU Press, The Australian National University, Canberra, Australia.

doi.org/10.22459/TA54.2021.12 